\title{
Isolated or associated experimental contamination of albumen and egg yolk for Salmonella Enteritidis and Escherichia coli - influence of temperature and storage time
}

\author{
[Contaminação experimental de albúmen e gema de ovos por Salmonella Enteritidis e Escherichia coli \\ isoladas ou associadas - influência da temperatura e tempo de armazenagem]

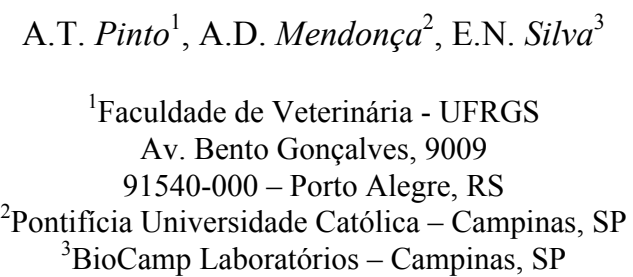

ABSTRACT

The behavior of Salmonella Enteritidis (SE) and Escherichia coli in albumen and yolk of chicken eggs submitted to two different temperatures, $8^{\circ} \mathrm{C}$ and $30^{\circ} \mathrm{C}$, when separately inoculated or in the form of mixed cultures was studied. There was no difference in the behaviour of the tested agents even when inoculated together. Even under high temperature, E. coli did not multiply in the albumen, demonstrating the inhibition power for that microorganism, while SE increased its population up to three logarithmic cycles. In egg yolk, SE demonstrated psychrotrophic characteristics.

Keywords: chicken, egg quality, bacterial growth, temperature, storage

\section{RESUMO}

Avaliou-se o comportamento de Salmonella Enteritidis (SE) e Escherichia coli em albúmen e gema de ovos de galinha, submetidos a duas diferentes temperaturas, 8 e $30^{\circ} \mathrm{C}$, quando inoculadas isoladamente ou na forma de culturas mistas. Não houve diferença no comportamento dos agentes testados mesmo quando inoculadas em conjunto. Mesmo sob temperatura alta, E. coli não se multiplicou no albúmen, demonstrando o poder inibidor de seus constituintes para esse microrganismo, enquanto a SE aumentou sua população em até três ciclos logarítmicos. Em gema de ovo, SE demonstrou características psicrotróficas.

Palavras-chave: galinha, qualidade do ovo, multiplicação bacteriana, temperatura, armazenagem

\section{INTRODUCTION}

Salmonella spp. is the most important etiologic agent for human gastroenteritis all over the world (Guidelines..., 1983) and, in recent years, $S$. Enteritidis (SE) has been the most prevalent serotype in Brazil (Tavechio et al., 2002; Nunes et al., 2003).

Different enteric pathogenic bacteria such as Salmonella spp. and Escherichia coli can contaminate the components of the eggs leading to food poisoning. These genera can contaminate eggs separately or together.

Temperature, $\mathrm{pH}$, and antimicrobial substances are limiting growth factors in the albumen (Yadav and Vadehra, 1977; Tranter and Board, 1982; Tranter and Board, 1984; Baron et al., 1997a; Gast and Holt, 2001). However, there are no limiting growth factors in the egg yolk so, when the environmental factors are favourable,

Recebido em 21 de maio de 2008 
bacteria can easily grow (Tranter and Board, 1982).

Few studies are available on the behaviour of SE and $E$. coli when inoculated into the eggs as mixed cultures. In other biological systems, like pig slurry treatment, these bacteria have negative correlation coefficient (Schmidt and Cardoso, 2003).

This research aimed to obtain information about SE and E. coli behavior in egg yolk and albumen when submitted to different storage temperatures.

\section{MATERIAL AND METHODS}

Mutant pathogenic $S E$ phage type 4 and a nonpathogenic $E$. coli, both resistant strains to nalidixic acid and novobiocin $(100 \mu \mathrm{g} / \mathrm{mL}$ each), isolated from commercial chicken, were used in this study. Both organisms were cultured in tryptic soy broth (TSB) at $35^{\circ} \mathrm{C}$ for 20 hours, when the population counts reached $9.0 \mathrm{log}$ colony forming units $(\mathrm{CFU}) / \mathrm{mL}$. Then, they were inoculated separately and mixed into the albumen and yolk preparations using sterile pipettes.

Less than 24 hours after chicken eggs were laid, they were disinfected by immersion in an ethyl alcohol $\left(70^{\circ} \mathrm{GL}\right)$ solution for 10 minutes and allowed to dry in a laminar flow chamber. The eggs were broken and the albumen and the yolk were aseptically separated, placed in sterile plastic bags (pool of 15 eggs/each experiment), and gently hand homogenized before and after inoculation. The count for both microorganisms was $2.0 \log$ CFU per gram of egg preparation. The plastic bags were sealed and incubated at $30^{\circ} \mathrm{C}$ and $8^{\circ} \mathrm{C}$ for fourteen days. The tested eggs came from a free Salmonella farm.

Before each analysis, the egg contents of the plastic bags were hand homogenized and samples $(5 \mathrm{~mL})$ were taken using sterile pipettes. These samples were first suspended in $45 \mathrm{~mL}$ of buffered peptone water (BPW), serial decimal dilutions prepared in BPW and $0.1 \mathrm{~mL}$ of each dilution surface-plated onto McConkey agar containing nalidixic acid and novobiocin $(100 \mu \mathrm{g} / \mathrm{mL}$ of culture media). Colonies that grew on the agar were counted after $24-48$ hours of incubation at $35^{\circ} \mathrm{C}$.

The samples were taken after $0,2,6,12,16$, and 24 hours when the incubation temperature was $30^{\circ} \mathrm{C}$; and after $0,6,12,16$, and 24 hours when the incubation temperature was $8^{\circ} \mathrm{C}$. In addition, further samples were taken after $48,72,168$, and 336 hours at incubation temperatures of $8^{\circ} \mathrm{C}$ and $30^{\circ} \mathrm{C}$.

The $\mathrm{pH}$ values of the samples of albumen and yolk were measured using $\mathrm{pH}$ paper ${ }^{1}$ every 24 hours, before the enumeration procedures.

The data for bacterial growth were submitted to variance analysis, using Statistica 5.5 (Datasoft Inc.)

\section{RESULTS AND DISCUSSION}

Fig. 1 shows the results for the growth of SE and $E$. coli at $30^{\circ} \mathrm{C}$, both separately and together. The growth of each microrganism was not statistically affected when mixed cultures were inoculated into the albumen $(\mathrm{P}<0.05)$.

The counts of SE reached 5.0 to $6.0 \mathrm{log} \mathrm{CFU} / \mathrm{g}$ and did not alter for the $336 \mathrm{~h}$ observation period. On the other hand, E. coli counts only decreased to $1.0 \log \mathrm{CFU} / \mathrm{g}$ and there were no viable cells at the end of the same period. Thus, it seems that the cells of this specific strain of SE were much more resistant to the antimicrobial substances present in the albumen than those of $E$. coli.

The antimicrobial activity of albumen is more effective against Gram-positive bacteria, although there is some activity against Gramnegative ones (Yadav and Vadehra, 1977; Tranter and Board, 1982; Tranter and Board, 1984; Baron et al., 1997a; Gast and Holt, 2001). This experiment showed that $\mathrm{SE}$ is resistant to the unfavourable conditions of the albumen.

These results agree with Baron et al. (2004) who showed that the growth of Salmonella sorovars in albumen at $30^{\circ} \mathrm{C}$ was unaffected by those conditions, including their pathogenic characteristics. Salmonella can overcome the deficiency of iron by secreting siderophors that allow their growth in albumen, using the iron for

${ }^{1}$ Neutralit pH 5.0-10.0 - Merck - São Paulo, Brazil. 
their metabolism (Baron et al., 1997b). E. coli showed a different pattern. Albumen was an unfavourable medium for this organism at $30^{\circ} \mathrm{C}$ and no viable cells were found at the end of the experiment. At this temperature, the antimicrobial characteristics can be effective against some Gram-negative bacteria. There is no consensus about the behavior of $E$. coli in albumen at $30^{\circ} \mathrm{C}$. Yadav and Vadehra (1977) studied a strain of $E$. coli and found that this microorganism was capable of growing in albumen at $30-32^{\circ} \mathrm{C}$. Tranter and Board (1984) found that $E$. coli could not grow in albumen when incubated at this same temperature, and could die. They believed that the albumen had more antimicrobial activity at this temperature than when it was incubated at lower temperatures.
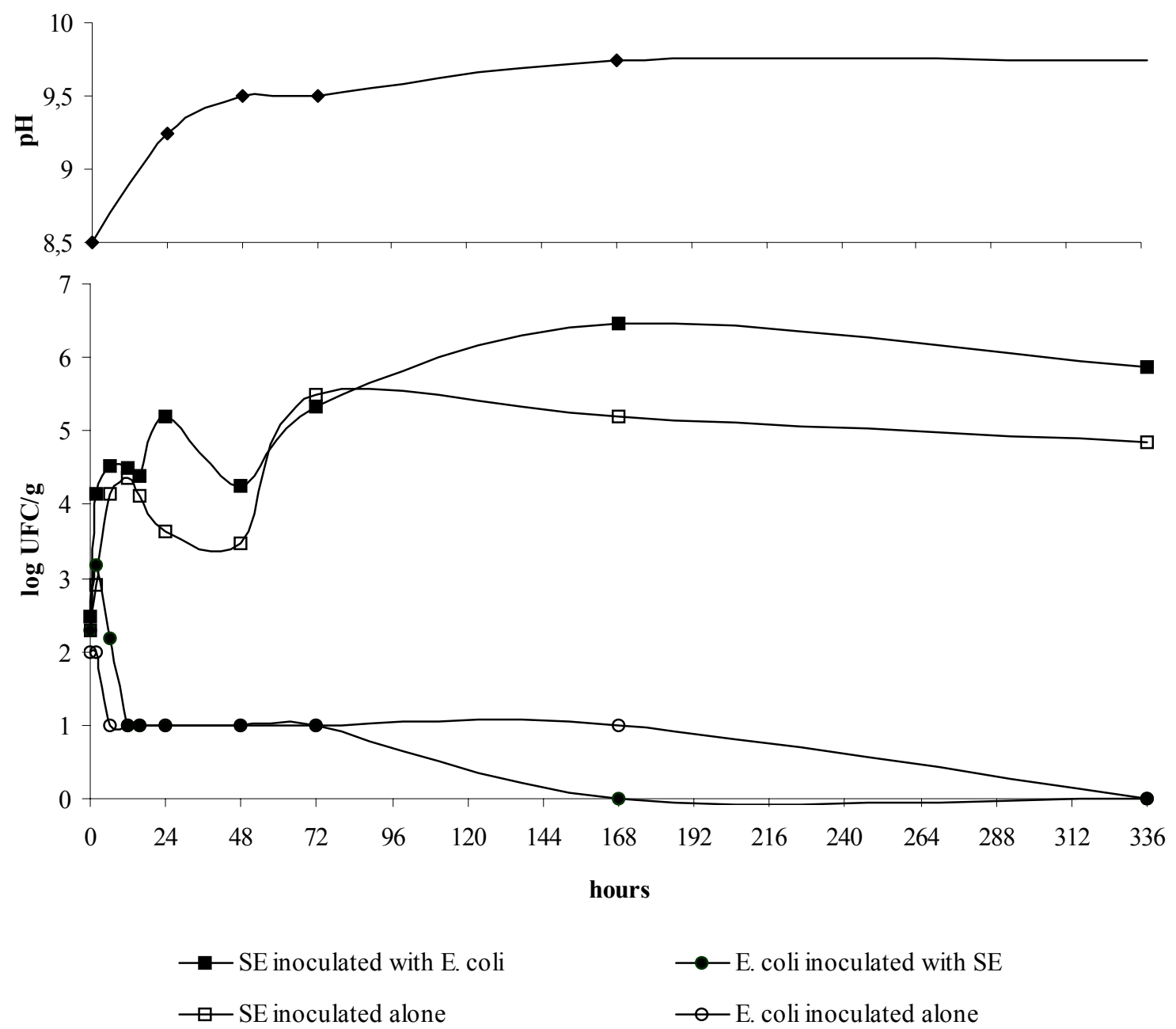

Figure 1. Salmonella Enteritidis and Escherichia coli behavior in albumen incubated at $30^{\circ} \mathrm{C}$.

The $\mathrm{pH}$ value increased from 8.5 to 9.5 during the first 48 hours and there were no further changes. The inoculation of both bacteria did not change the $\mathrm{pH}$ (Figure 1).

Fig. 2 shows the results for the growth of SE and E. coli at $8^{\circ} \mathrm{C}$. At this temperature, the SE count declined but maintained its viability until the end of the experiment. It shows that the temperature affects the behaviour of SE. There was also statistical difference between the behaviors of this bacteria at 8 and $30^{\circ} \mathrm{C}(\mathrm{P}<0.05)$. 

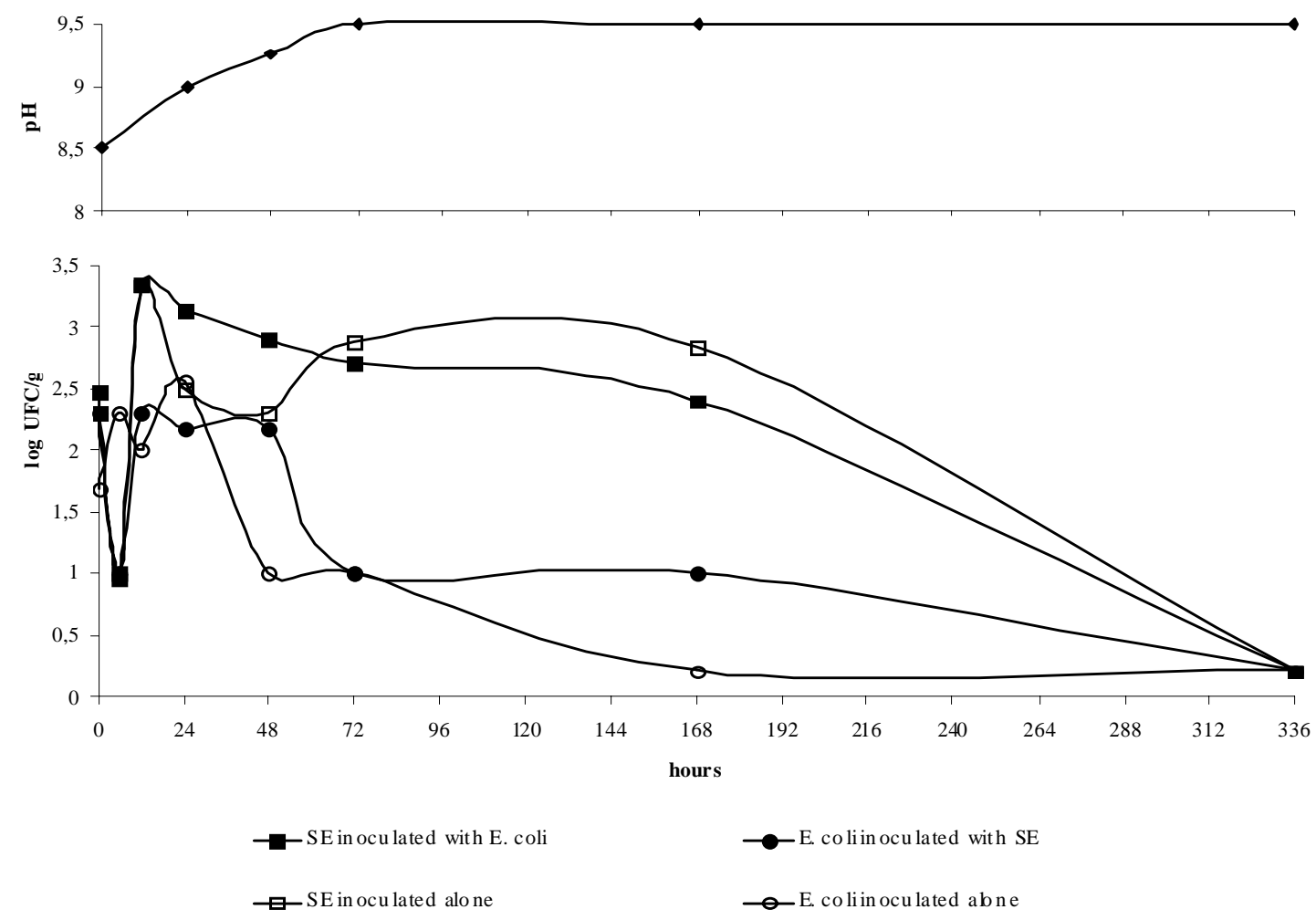

Figure 2. Salmonella Enteritidis and Escherichia coli behavior in albumen incubated at $8^{\circ} \mathrm{C}$.

Gast and Holt (2000) found little variability in SE growth at different temperatures $(10,17.5$, and $25^{\circ} \mathrm{C}$ ). At refrigeration temperatures, the number of viable cells rose slowly and the risk of disease was lower than when stored at higher temperatures. The success of the cooling process depends on the time lapse between the start of the temperature decrease and the minimum inhibitory temperature (Gast and Holt, 2001). Otherwise, Salmonella can grow in food stored at low temperatures such as $2^{\circ} \mathrm{C}$ (Angelotti et al., 1961; Matches and Liston, 1968; Palumbo 1986; D’Aoust, 1991). However, Gibson et al. (1988) had difficulty in fitting the growth curves at low temperatures. This is why it is so difficult to anticipate bacterial behavior at refrigeration temperatures.

E. coli cells were viable in the albumen preparation stored at $8^{\circ} \mathrm{C}$ for $336 \mathrm{~h}$, until the end of the experimental period. This pattern was different from that at $30^{\circ} \mathrm{C}$, when no viable cells were found at the end. Lower temperatures allowed bacterial viability. Albumen can be more toxic to bacterial cells at higher temperatures (Tranter and Board, 1984). In the current study, it was noticed that $E$. coli was more fragile than $\mathrm{SE}$ in the albumen at $8^{\circ} \mathrm{C}$. This is explained by the capacity of SE to reach the yolk and multiply, giving rise to outbreaks of foodborne disease.

The storage temperature affected the $\mathrm{pH}$ curve in the albumen preparations. At $8^{\circ} \mathrm{C}$, the $\mathrm{pH}$ rose slower than at $30^{\circ} \mathrm{C}$ (Fig. 2), reaching the value 9.5 after 72 hours, 24 hours later than at $30^{\circ} \mathrm{C}$. The highest $\mathrm{pH}$ level was the same at both storage temperatures. These results are similar to those of Sabrani and Payne (1978). The inoculated bacteria did not affect albumen alkalinity $(\mathrm{P}<0.05)$.

Both SE and E. coli grew in the egg yolk preparations and reached 7.5-8.7 $\log \mathrm{CFU} / \mathrm{g}$ at $30^{\circ} \mathrm{C}$ in the first 24 hours after inoculation. Growth slowed down after this period and became stable after 48 hours (Fig. 3). Both bacteria showed the same growth pattern regardless of the inoculation conditions as a single or mixed culture, with no statistical difference $(\mathrm{P}<0.05)$. 


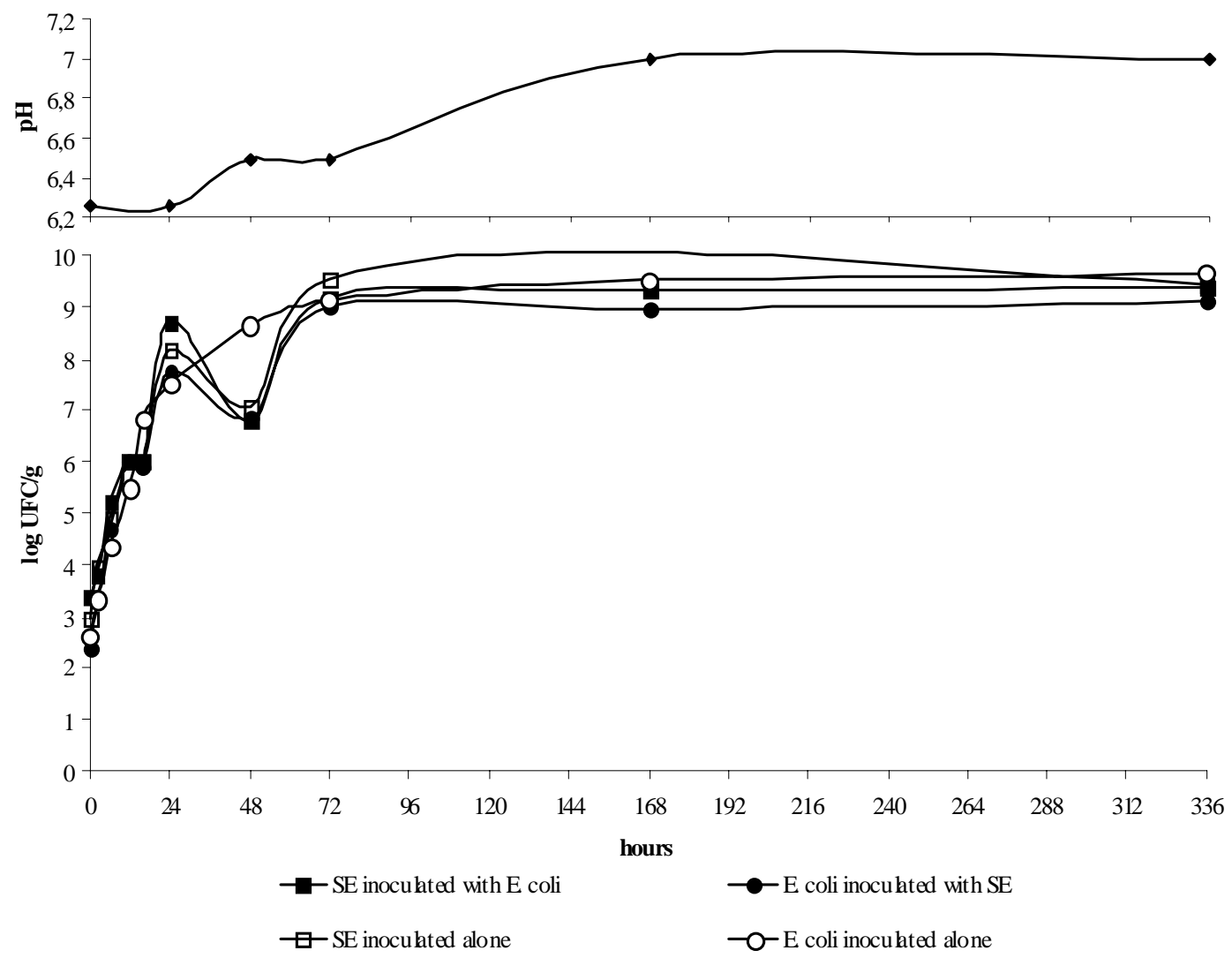

Figure 3. Salmonella Enteritidis and Escherichia coli behavior in egg yolk incubated at $30^{\circ} \mathrm{C}$.

Yolk, unlike other egg structures, contains no anti-bacterial growth elements (Tranter and Board, 1982). This is why bacteria can reach high counts in yolk. These results correlated with other reports, in which different phage types of $\mathrm{SE}$ (PhT4, 8, 13a, and 14b) were inoculated into egg yolk and incubated at $25^{\circ} \mathrm{C}$, all showed similar growth behavior (Gast and Holt, 2001).

Egg yolk is an excellent culture media, and even a small contamination can reach high levels $(8.0$ $\log \mathrm{CFU} / \mathrm{g}$ ), leading to foodborne diseases. SE, in high counts, can survive any heat or cooking treatment (Humphrey et al., 1989). Viable cells of SE have been found in $44 \%$ of all fried, scrambled, hard-cooked eggs, and omelettes prepared with contaminated eggs (Mahdi Saeed and Koons, 1993).

The storage temperature affected the $\mathrm{pH}$ curve in the egg yolk preparations, but the inoculation condition of being a single bacteria or a mixed culture did not $(\mathrm{P}<0.05)$. The yolk $\mathrm{pH}$ rose slightly throughout the experimental period. The
$\mathrm{pH}$ rose slower at lower temperatures than at higher ones.

The storage temperature had a marked effect on the growth of SE and E. coli in the egg yolk preparations. At $8^{\circ} \mathrm{C}$ (Fig. 4), SE remained viable and the growth of E. coli was inhibited. After the $336 \mathrm{~h}$ of the experimental period, the SE counts had risen to 4.5 and 4.8 and the $E$. coli counts had reduced to $0.20 \log \mathrm{CFU} / \mathrm{g}$. SE can grow in egg yolk preparations kept at refrigeration temperatures $\left(10^{\circ} \mathrm{C}\right)$, but not at lower temperatures $\left(<7.2^{\circ} \mathrm{C}\right)$. The present research showed that SE could be a health problem even when egg yolk is stored at low temperatures, because it keeps its viability and it can reach high counts as the temperature increases.

The behavior of these microorganisms is also affected by the $\mathrm{pH}$, that has different values in albumen and yolk. The $\mathrm{pH}$ of the yolk is more adequate to bacterial growth. 

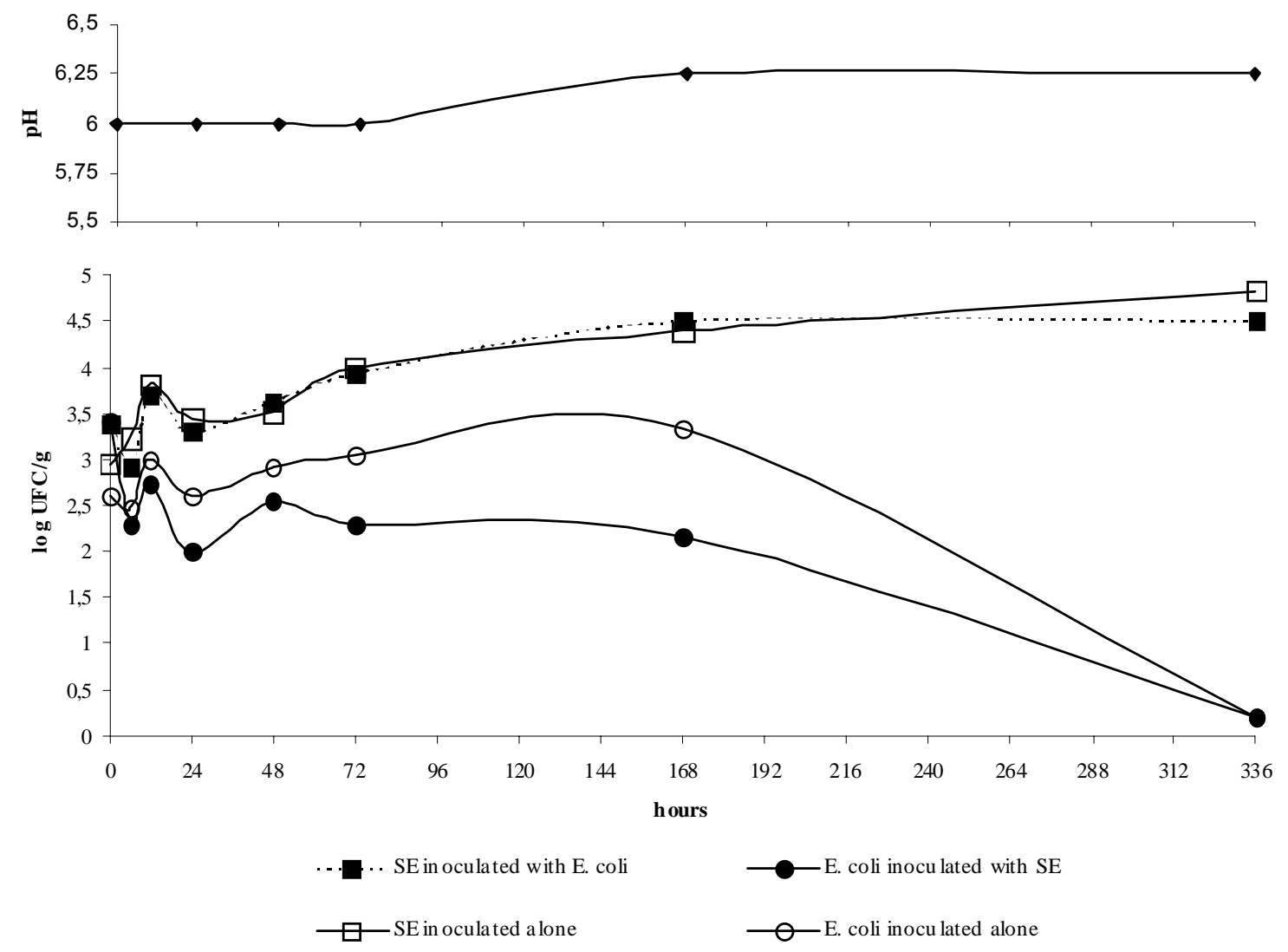

Figure 4. Salmonella Enteritidis and Escherichia coli behavior in egg yolk incubated at $8^{\circ} \mathrm{C}$.

\section{CONCLUSIONS}

Despite of SE and E. coli belong to the same family (Enterobactereaceae), they have different behavior in egg. SE showed resistance against the antimicrobial activity of the albumen even under high temperatures $\left(30^{\circ} \mathrm{C}\right)$, while $E$. coli had the development inhibited. In albumen, cooling temperatures $\left(8^{\circ} \mathrm{C}\right)$ allowed the survival of both bacteria at the end of the experiment. In egg yolk, Salmonella can grow even at low temperatures, while E. coli is inhibited.

\section{ACKNOWLEDGEMENTS}

This research was supported by FAPESP and CAPES.

\section{REFERENCES}

ANGELOTTI, R.; FOTER, M.J.; LEWIS, K.H. Time-temperature effect on salmonellae and staphylococci in foods. I. Behavior in refrigerated foods. Am. J. Public Health., v.51, p.76-83, 1961.

BARON, F.; GAUTIER, M.; BRULE, G. Factors involved in the inhibition of growth of Salmonella enteritidis in liquid egg white. $J$. Food Prot., v.60, p.1318-1323, 1997 a.

BARON, F.; GAUTIER, M.; BRULE, G. Growth inhibition of Salmonella enteritidis in liquid egg white. In: CONGRESS SALMONELLA AND SALMONELLOSIS, 1997, Ploufragan. Proceedings... Ploufragan, 1997b. p.347-350.

BARON, F.; BRIANDET, R.; LESNE, J. et al. Influence of a nonfavorable environment, egg white, on resistance to heat and disinfectant, adhesion, and virulence of Salmonella Enteritidis. J. Food Prot., v.67, p.2269-2273, 2004.

D'AOUST, J.Y. Psychrotrophy and foodborne Salmonella. Int. J. Food Microbiol., v.13, p.207216, 1991. 
GAST, R.K.; HOLT, P.S. Influence of the level and location of contamination on the multiplication of Salmonella enteritidis at different storage temperatures in experimentally inoculated eggs. Poult. Sci., v.79, p.559-563, 2000.

GAST, R.K.; HOLT, P.S. Multiplication in egg yolk and survival in egg albumen of Salmonella enterica serotype Enteritidis strains of phage types 4, 8, 13a, and 14b. J. Food Prot., v.64, p.865-868, 2001

GIBSON, A.M.; BRATCHELL, N.; ROBERTS, T.A. Predicting microbial growth: growth responses of salmonellae in a laboratory medium as affected by $\mathrm{pH}$, sodium chloride and storage temperature. Int. J. Food Microbiol., v.6, p.155178,1988

GUIDELINES on Prevention and Control of Salmonellosis. Geneve: WHO, 1983.

HUMPHREY， T.J.; GREENWOOD， M.; GILBERT, R.J. et al. The survival of salmonellas in shell eggs coocked under simulated domestic conditions. Epidemiol. Infect., v.103, p.34-45, 1989.

MAHDI-SAEED, A.; KOONS, C.W. Growth and resistance of Salmonella enteritidis in refrigerated and abused eggs. J. Food Prot., v.56, p.927-931, 1993.

MATCHES, J.R., LISTON, J. Low temperature growth of Salmonella. J. Food Sci., v.33, p.641645,1968
NUNES, I.A.; HELMUTH, R.; SCHROETER, A. et al. Phage typing of Salmonella Enteritidis from different sources in Brazil. J. Food Prot., v.66, p.324-32, 2003.

PALUMBO, S.A. Is refrigeration enough to restrain foodborne pathogens? J. Food Prot., v.49, p.1003-1009, 1986.

SABRANI, M.; PAYNE, C.G. Effect of oiling on internal quality of eggs stored at 28 and $12^{\circ} \mathrm{C}$. Br. Poult. Sci., v.19, p.567-571, 1978.

SCHMIDT, V.; CARDOSO, M. Sobrevivência e perfil de resistência a antimicrobianos de Salmonella sp. isoladas em um sistema de tratamento de dejetos de suínos. Cienc. Rural, v.33, p.881-888, 2003

TAVECHIO, A.T.; GHILARDI, A.C.R.; PERESI, J.T.M. et al. Salmonella serotypes isolated from nonhuman sources in São Paulo, Brazil, from 1996 through 2000. J. Food Prot., v.65, p.1041-1044, 2002.

TRANTER, H.S.; BOARD, R.G. The antimicrobial defense of avian eggs: biological perspective and chemical basis. J. Appl. Biochem., v.4, p.295-338, 1982.

TRANTER, H.S.; BOARD, R.G. The influence of incubation temperature and $\mathrm{pH}$ on the antimicrobial properties of hen egg albumen. $J$. Appl. Microbiol., v.56, p.53-61, 1984.

YADAV, N.K.; VADEHRA, D.V. Mechanism of egg white resistance to bacterial growth. $J$. Food Sci., v.42, p.97-99, 1977. 